\title{
Nitric oxide as an indicator for assessing the resistance and susceptibility of cattle to leukemia
}

\author{
U. Zh. Kuzhebayeva ${ }^{1 凶}$, I. M. Donnik ${ }^{2}$, M. V. Petropavlovskiy², S. G. Kanatbaev³ , B. E. Nurgaliev ${ }^{1}$ \\ ${ }^{1}$ Zhangir Khan West Kazakhstan Agrarian-Technical University, Uralsk, Kazakhstan \\ ${ }^{2}$ Ural Federal Agrarian Scientific Research Center of Ural Branch of the Russian Academy of Sciences, \\ Ekaterinburg, Russia \\ ${ }^{3}$ West Kazakhstan Innovative and Technological University, Uralsk, Kazakhstan \\ ¿E-mail:usya_999@mail.ru
}

Abstract. The role of allelic variability of inducible nitric oxide synthase (iNOS) is significant in the study of the resistance and susceptibility of animals to leukemia infection. After analyzing the literature data, it can be stated that in the iNOS gene, allele A (with genotype AA) is responsible for resistance to the leukemia virus, and allele B (with genotype BB) is responsible for susceptibility. This is due to the frequency of occurrence of alleles and their genotypes of the polymorphic marker AN13-1 of the inducibeal nitric oxide synthase gene. The iNOS gene is capable of producing a large amount of nitric oxide, compared to other isoforms. In turn, nitric oxide causes death or can stop the growth of pathogenic microorganisms, including viruses. The purpose of this work is to further study nitric oxide as an indicator for determining the resistance and susceptibility of animals to leukemia, as well as the selection of specific primers for PCR-PDRF used in genotyping. Methods. The iNOS gene sequence was analyzed and a pair of specific primers were selected and synthesized using the Vector NTI program. Scientific novelty of ing by allelic variants of the polymorphic marker AH13-1 of the iNOS gene. Results. Based on this work, a pair of primers iNOSF_new and iNOSR_new, with a calculated annealing temperature of $52{ }^{\circ} \mathrm{C}$, were selected and synthesized, giving an amplicon with a length of $186 \mathrm{bp}$. The amplicon contains a polymorphic site that distinguishes the A and B alleles. During PCR-RFLP, the following genotype-specific fragments are formed: AA-47/139 bp; AB -186/139/47 bp; BB-186 bp.

Keywords: leukemia, bovine, interleukin, nitric oxide, oligonucleotides, resistance, susceptibility, polymorphic.

For citation: Kuzhebayeva U. Zh., Donnik I. M., Petropavlovskiy M. V., Kanatbaev S. G., Nurgaliev B. E. Nitric oxide as an indicator for assessing the resistance and susceptibility of cattle to leukemia // Agrarian Bulletin of the Urals. 2021. No. 10 (213). Pp. 48-54. DOI: 10.32417/1997-4868-2021-213-10-48-54.

Date of paper submission: 27.08.2021, date of review: 02.09.2021, date of acceptance: 06.09.2021.

\section{Introduction}

Currently, one of the widespread viral diseases causing significant economic damage to the cattle breeding industry is bovine leukemia [1, p. 1058], [2, p. 3688], [3, p. 255]. In the Republic of Kazakhstan, this disease was first registered in early 1966 in two farms of the Karaganda region and in one farm of the Almaty region among young cattle of brown Latvian and red Lithuanian breeds imported in 1960 from the Baltic republics. In 1969 , the number of disadvantaged settlements increased to 22 , in 1970 - to 49 and in 1983 - to 186 in 14 regions of the republic. To date, the disease has been registered in 12 out of 14 regions on the territory of the Republic of Kazakhstan. According to the "National Reference Center for Veterinary Medicine" and the "Republican Veterinary Laboratory" of the Ministry of Agriculture of the Republic of Kazakhstan for 2015-2018, $0.44 \%$ of the total number of cattle were examined, the degree of infection was $5.8 \%$ [4, p. 150], [5, p. 79]. In the Russian Federation, the leukemia virus is established on the 48 territory of 64 subjects, according to official data, the number of disadvantaged leukemia sites in the Russian Federation reaches 1789 [6, p. 8].

Bovine leukemia virus is an RNA-containing oncogenic virus that causes malignant lymphoproliferative disease of animals. According to the classification of the International Committee for Taxonomy of Viruses (ICTV), it belongs to the family Retroviridae (2 subfamilies, 7 genera), the subfamily Orthoretrovirinae, the genus Deltaretrovirus, which also includes T-lymphotropic primate viruses (PTLV) - humans and monkeys (HTLV and STLV).

According to the authors involved in the study of leukemia, it is known that almost $70 \%$ of infected animals have an asymptomatic disease, the aleikemic stage. However, after a few years of the asymptomatic period, $25-30 \%$ of animals infected with the leukemia virus develop persistent lymphocytosis characterized by polyclonal expression of the neoplastic population of CD5+ B lymphocytes, and 1-5\% develop B-cell lymphoma [7]. 
Agrarian Bulletin of the Urals No. 10 (213), 2021

However, a mechanism capable of providing protection against enzootic leukemia for cows infected with leukemia is still unknown.

The leukemia virus can be transmitted vertically and horizontally, as well as during procedures related to the transfer of infected blood between animals, such as needle reuse, horn amputation, rectal palpation, tattooing, the so-called iatrogenic pathway [8].

It is worth noting the importance of the influence of the level of proviral load (PVL) on the course of the infectious process. The level of proviral load is the amount of retroviral genome embedded in the host genome and associated with the progression of the disease. There are two profiles or phenotypes of the level of proviral load - high and low, which causes the transmission of the virus from infected to healthy animals. Animals with high levels of PLV are considered the main source of transmission and a risk factor for leukemia. According to the results of foreign studies, it was found that the level of PVL does not always correlate with the development of the hematological stage of the disease. To date, most researchers assume the relationship of allelic polymorphism of genes of cattle resistance to leukemia with the level of PVL. However, the biological mechanisms controlling the level of PVL and the progression of infection in cattle in relation to the breed and origin of animals have not been fully elucidated. The determination of the fundamental foundations of the biological mechanisms leading to the progression of BLV infection in cows is of great importance for the development of effective programs to combat the bovine leukemia virus [9].

Of significant importance in the development of leukemia infection is the natural resistance of the body and immunological reactivity, when infected with the leukemia virus, violations of cellular and humoral links of immunity are observed, as well as violations of erythro-, leuko-, and hematopoiesis with a simultaneous significant decrease in all metabolic reactions of the body.

It was found out that bovine leukemia is a disease with a hereditary predisposition due to genetic polymorphism, i.e. the existence in the population of several forms of a gene occurring with a certain frequency, serving as a measure of genetic variability of the population [10, p. 1440], [11, p. 14], as well as weak immunity often developing as a result of violations of the technology of maintenance and feeding. The manifestation of hereditary predisposition is determined by a complex of hereditary and external factors $[12$, p. 22], [13, p. 38], [14, p. 999]. To date, single nucleotide polymorphism (SNP) is widely used as a genetic marker for assessing DNA polymorphism, the high density of which makes it easy to identify a sufficient number of them near or inside the required gene. They are highly conservative, and they allow haplotype analysis of relatively short PCR fragments, thereby increasing the accuracy of the study. It is worth noting the importance of the analysis of the PDRF (polymorphism of the lengths of restriction fragments), in which the fragment is used as the simplest genetic marker. This analysis makes it possible to search for al- lelic variants of genes that determine the resistance and susceptibility of animals to infections [15, p. 107].

Due to the high economic costs caused by the disease, scientists are working to find an effective solution to the issue of selection and production of animals with low susceptibility to leukemia [16, p. 1063].

To date, studies on polymorphism in the main histocompatibility complex (MHC) of cattle by alleles of the BoLA gene are widely conducted. This highly polymorphic gene is registered in the Immuno-Polymorphism (IPD) - MHC database (https://www.ebi.ac.uk/ipd/mhc/ group/BoLA/) and serves as a marker for determining the disease, and also forms immunological signs in cattle. It is worth noting that along with MNS, the role of the influence of cytokine network genes, which in turn are involved in the pathogenesis of viral diseases, including bovine leukemia, has also been studied to date. Much attention is paid to the assessment of cytokine gene polymorphism and their role in pathology, since single nucleotide gene substitutions can affect the functional activity of genes, which in turn affects the course of the inflammatory process [17, p. 163].

Cytokines are low-molecular-weight soluble proteins that ensure the transmission of signals between cells, they are important both for the realization of innate and adaptive immunity [18, p. 154]. Cytokine synthesis is an inducible process that is triggered in response to the penetration of pathogens into the body, they are mainly released from immune cells, including monocytes, macrophages and lymphocytes. Proinflammatory cytokines chemokines play an important role in the study of the molecular mechanisms of the occurrence of pathological processes [19, p. 342], [20, p. 617]. They, in turn, interact with the mediator of apoptosis, with the regulator of the innate immunity system, short-lived nitric oxide (NO) molecules. It is NO that causes the cytotoxic effect of cells of the immune system or can stop the growth of pathogenic microorganisms, including viruses [21, p. 281].

In connection with the above, the purpose of this work is to study nitric oxide as an indicator for determining the resistance and susceptibility of animals to leukemia, as well as the selection of specific primers for PCR-RFLP used in genotyping.

\section{Methods}

We took the structure of locus-specific DNA fragments of the iNOS gene being analyzed from the DNA sequence database presented in the NCBI international database. Then, in the Primer-BLAST program, the selection of specific oligonucleotide primers was carried out, after which they were aligned in the BLAST program. The selection of primers for RFLP analysis was carried out by us in the Vector NTI program. We have selected primers suitable for the following characteristics: the length of the primers is $17-28 \mathrm{n}$; the percentage of $\mathrm{G}+\mathrm{C}$ pairs is $40-60$; to avoid sticking of the primers to itself; the formation of dimers; the melting point is in the range of $52-59^{\circ} \mathrm{C}$. 


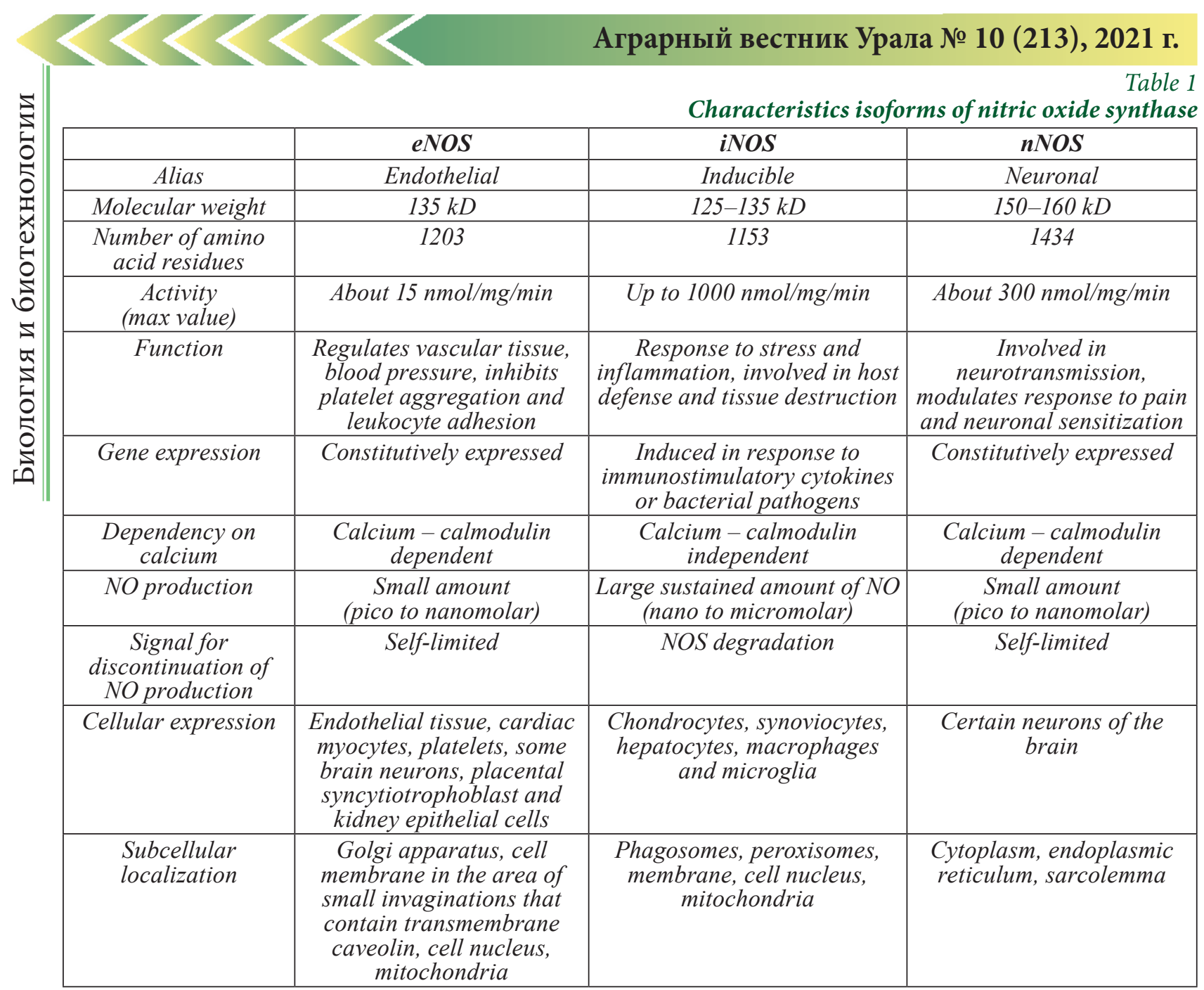

The forward and reverse sequences of oligonucleotides modeled by us were synthesized on the Expedite 8909 oligonucleotide synthesizer, Applied Biosystems. According to the protocols attached to the device, DNA synthesis was performed.

\section{Results}

To date, three isoforms of NO synthase (NOS) have been studied: neuronal (nNOS/NOS 1), endothelial (ENOS/NOS3), inducible (iNOS/NOS2). These isoforms are distinguished depending on the structure and localization. It is worth noting that the formation of nitrogen monoxide occurs as a result of the oxidation reaction by the $\mathrm{O}_{2}$ atom of $\mathrm{L}$-arginine in the presence of a specific enzyme NO-synthase. Table 1 shows the characteristics of isoforms of nitric oxide synthesis.

Under the influence of two isoforms (neuronal and endothelial), regulated, continuous, but low-intensity synthesis of nitric oxide occurs as a response to receptor and physiological stimulation. In turn, the isoform of nos that interests us consists of three types of NO synthases: NOS2A, NOS2B, NOS2C. This isoform appears in cells after their induction. Compared with other isoforms, this one shows the formation of a high concentration of nitric oxide, which has a cytotoxic effect. Inducible nitric oxide synthase is not present in most cells under normal conditions, however, in various malignant diseases, the intracellular mechanisms controlling iNOS are not regu- lated, which leads to constant expression and activation of iNOS. According to research data, S.Widdison iNOS of cattle shows great similarity with ios of other species and has a common protein domain [22, pp. 302-309].

The gene we are investigating is located on the 19th chromosome of cattle (Fig. 1).

It is also worth noting that 3 polymorphic markers A H 13-1, AH 13-2, AH 13-3 in the third intron are contained in the enos gene. In the works of S. V. Chichinina (2005) and H. H. Gilmanov (2019), the allelic polymorphism of the AH13-1 polymorphic marker of the iNOS gene was investigated, and the relationship of resistance and susceptibility of animals with the leukemia virus was established, previously in the works of M. P. Heaton (2001), the diversity of DNA sequences in the genes of cattle cytokines was assessed. For the analysis of cattle genotyping, a search for nucleotide sequences was performed. As a result, several genome sequences were identified and analyzed using the NCBI database (Fig. 2).

A genome with GenBank ID: AF465168 was used as a reference sequence. The genomic sequence of Bos taurus BTANOS2DS1 contains highly polymorphic single nucleotide sites. This genome consists of 258 bp (Fig. 3).

As a result, we selected 6 pairs of synthetic oligonucleotides per iNOS gene (Table 2).

According to the main criteria for PCR, a preliminary selection of a pool of primers was carried out. 


\section{Agrarian Bulletin of the Urals No. 10 (213), 2021}

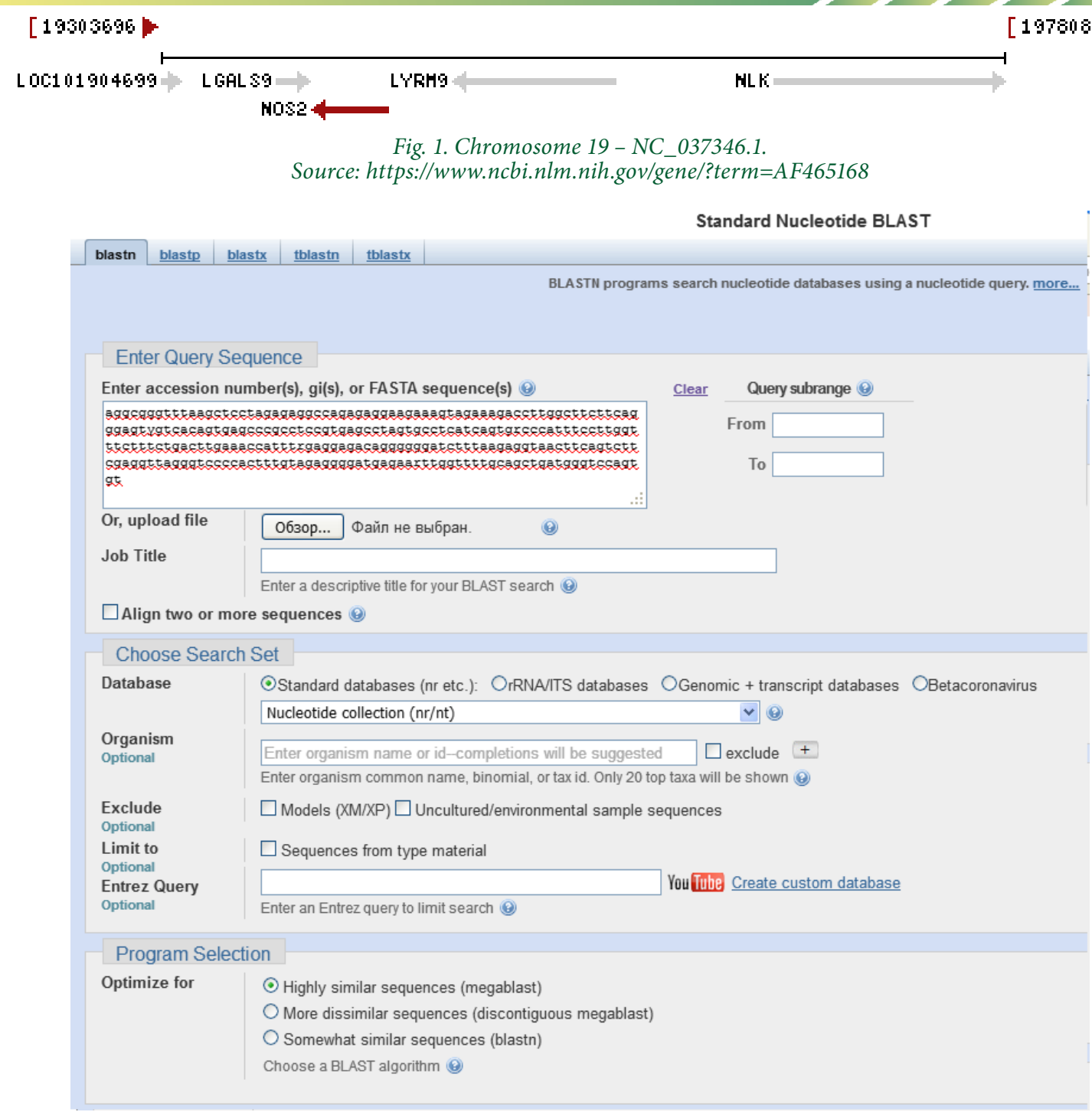

Source: https://www.ncbi.nlm.nih.gov/gene/?term $=$ AF465168

Fig. 2. Genome sequence analysis

Table 2

Combination of selected primer pairs

\begin{tabular}{|c|l|l|}
\hline No. & \multicolumn{1}{|c|}{ Forward primer } & \multicolumn{1}{|c|}{ Reverse primer } \\
\hline 1 & GGCGGGTTTAAGCTCCTAGA & GATGAGGCACTAGGCTCACG \\
\hline 2 & GAGCCTAGTGCCTCATCAGT & AAGTGGGGACCCTAACCTCG \\
\hline 3 & $A G A G G C C A G A G A G G A A G A A A G$ & GGACCCTAACCTCGAAGACTG \\
\hline 4 & $A G G C G G G T T T A A G C T C C T A G A$ & GGACCCTAACCTCGAAGACTG \\
\hline 5 & $A A A G A C C T T G G C T T C T T C A G G G$ & $A A A G T G G G G A C C C T A A C C T C G$ \\
\hline 6 & $A G A G G C C A G A G A G G A A G A A A G T$ & GGGGACCCTAACCTCGAAGAC \\
\hline
\end{tabular}

The next step was to check the specificity of the selected primers using the BLAST program, primers with $100 \%$ specificity were selected. After that, we selected primers for PDRF analysis using the Vector NTI program (Fig. 4). Primers with an estimated annealing temperature of $52{ }^{\circ} \mathrm{C}$ were selected, giving an amplicon with a length of $186 \mathrm{bp}$. The amplicon contains a polymorphic site that distinguishes the A and B alleles. Allele A contains a HinfI restriction site, the PCR product obtained from it is cut into fragments 47 and $139 \mathrm{bp}$ long. Allele B does not contain a HinfI restriction site.
Thus, during PCR-PDRF, the following genotypespecific fragments are formed: AA - 47/139 bp; AB 186/139/47 bp; BB - 186 bp (Table 3).

Automatic synthesis of oligonucleotides was carried out using special devices - DNA synthesizers. The synthesis of the primer was carried out by gradual completion of the nucleotide, according to its nucleotide sequence. 


Аграрный вестник Урала № 10 (213), 2021 г.
Table 3
Primer sequence and PCR-RFLP genotype profiles of the iNOS gene
Primer

\section{Bos taurus BTANOS2DS1 genomic sequence containing highly polymorphic single nucleotide sites} Sequence ID: AF465168.1 Length: 258 Number of Matches: 1

Range 1: 1 to 258 GenBank Graphics

$\nabla$ Next Match $\triangle$ Previous Match

\begin{tabular}{|c|c|c|c|c|c|c|}
\hline \multicolumn{2}{|c|}{$\begin{array}{l}\text { Score } \\
462 \text { bits }(250)\end{array}$} & $\begin{array}{l}\text { Expect } \\
4 \mathrm{e}-126\end{array}$ & $\begin{array}{l}\text { Identities } \\
258 / 258(100 \%)\end{array}$ & $\begin{array}{l}\text { Gaps } \\
0 / 258(0 \%)\end{array}$ & $\begin{array}{l}\text { Strand } \\
\text { Plus/Plus }\end{array}$ & \\
\hline Query & 1 & \multicolumn{4}{|c|}{ 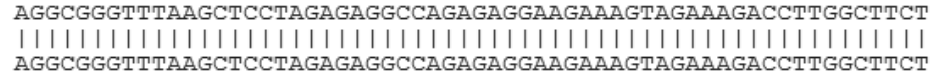 } & 50 \\
\hline Sbjet & 1 & \multicolumn{4}{|c|}{ AGGCGGGTTTAAGCTCCTAGAGAGGCCAGAGAGGAAGAAAGTAGAAAGACCTTGGCTTCT } & 60 \\
\hline Query & 61 & \multirow{2}{*}{\multicolumn{4}{|c|}{ 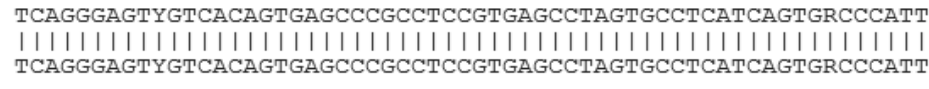 }} & \\
\hline sbjet & 61 & & & & & \\
\hline Query & 121 & \multirow{2}{*}{\multicolumn{4}{|c|}{ 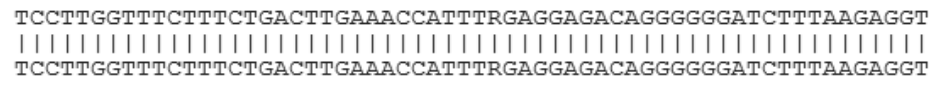 }} & \\
\hline Sbjet & 121 & & & & & \\
\hline Query & 181 & \multicolumn{4}{|c|}{$\begin{array}{l}\text { AACTTCAGTCTTCGAGGTTAGGGTCCCCACTTTGTAGAGGGGATGAGAARTTGGTTTTGC } \\
||||||||||||||||||||||||||||||||||||||||||||||||||||||||||||\end{array}$} & \\
\hline Sbjet & 181 & \multicolumn{4}{|c|}{ AACTTCAGTCTTCGAGGTTAGGGTCCCCACTTTGTAGAGGGGATGAGAARTTGGTTTTGC } & \\
\hline Query & 241 & \multicolumn{4}{|c|}{$\begin{array}{l}\text { AGCTGATGGGTCCAGTGT } 258 \\
||||||||||||||||||\end{array}$} & \\
\hline Sbjet & 241 & AGCTGATGGGTC & GTGT 258 & & & \\
\hline
\end{tabular}

Fig. 3. Bos taurus BTANOS2DS1 genomic sequence containing highly polymorphic single nucleotide sites

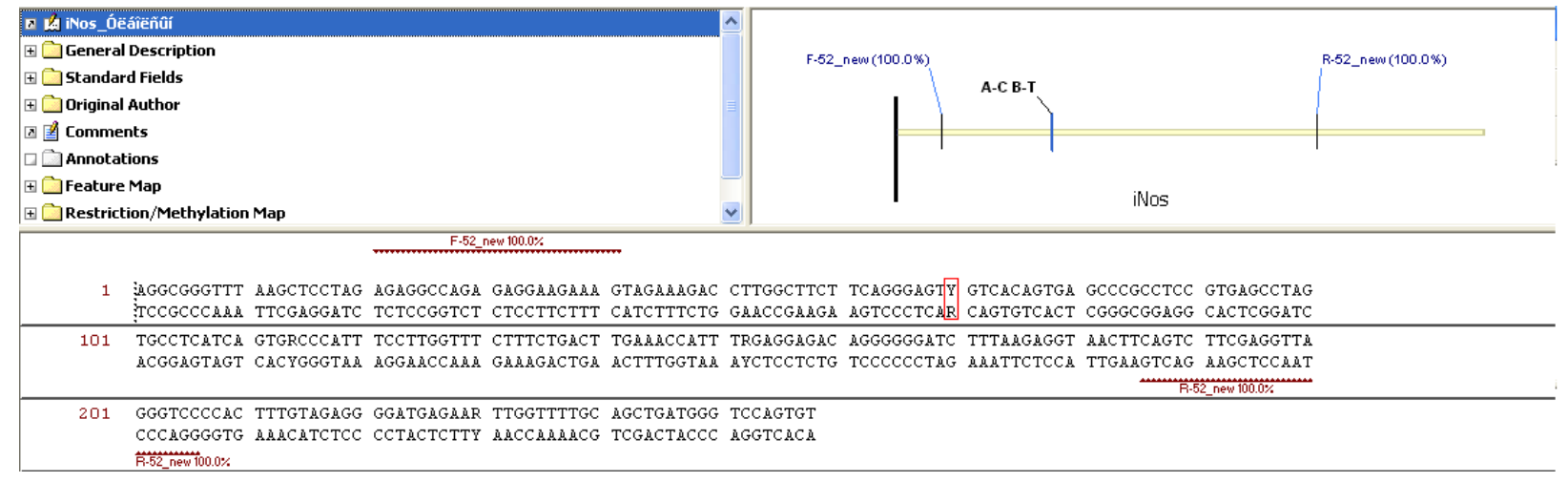

Fig. 4. Selection of primers in the program "Vector NTI". The polymorphic site is highlighted with a red rectangle

\section{Discussion and Conclusion}

As mentioned above, bovine leukemia is a problem of the livestock industry all over the world, leading to significant economic losses due to premature death of animals from lymphomas, loss of carcasses during slaughter, reduced milk yield and reduced immunity of animals, as well as the impact on reproductive ability and longevity. In this regard, the search for genetically stable animal breeds is relevant today.

According to V. L. Petukhov (1992), animals that do not get sick for a long period, as well as breeding bulls with a low degree of daughter disease, are characterized by a high concentration of resistance genes and the duration of the body's resistance to pathogens, depends on the number of corresponding genes present in the genotype of animals.
In studies of animal resistance to leukemia, an active study of the allelic structure of the BoLA-DRB3 gene is currently underway, along with it, it is worth noting the role of the iNOS gene also responsible for resistance to infectious diseases.

Inducibeal nitric oxide synthase is an enzyme that catalyzes the formation of nitric oxide. In turn, as noted in the literature, NO is an important signaling molecule, which in turn is released by a large number of cells acting in many tissues. It has a regulating effect on a wide range of physiological and biological processes, such as neurotransmission, immune protection and apoptosis.

Earlier, in the works of S. V. Chichinina, H. H. Gilmanov, work was carried out to study the iNOS gene and its haplotypes. The allelic polymorphism of the iNOS gene is evaluated and the genotypic structure of the ana- 
lyzed animal population is established in the context of genetic resistance and sensitivity to infection. The possibility of using this gene as an SNP marker for cattle identification was studied. An associative relationship was established between the genotypes of the polymorphic marker AH13-1 of the iNOS gene of cattle and their breeding value in terms of milk productivity.

Thus, we searched for complete nucleotide sequences of the iNOS gene for the analysis of cattle genotyping. A comparative analysis and multiple alignment of the complete nucleotide sequences of the gene were carried out. And based on the analysis of gene sequences, using the Vector NTI program, primers for PDRF analysis were selected. And the synthesis of specific primers was carried out - iNOSF_new: 5'-AGAGGCCAGAGAGGAAGAAG-3', iNOSR_new: 5'-GGACCCTAACCTCGAAGACTG-3', in the required amount on the oligonucleotide synthesizer, according to the manufacturer's protocols. Genotype-specific fragments were also identified: AA - 47/139 bp; AB - 186/139/47 BP; BB - 186 bp formed during PCR-RFLP analysis.

Such studies, to determine the resistance and susceptibility of animals, can be used to monitor the potential of genetic resistance of a population to leukemia, which makes it possible to plan long-term breeding work in order to combat the disease, as well as to develop animal breeding programs for individual farms that are disadvantaged by bovine leukemia.

\section{References}

1. Bartlett P. C., Ruggiero V. J., Hutchinson H. C., Droscha C. J., Norby B., Sporer K. R., Taxis T. M. Current developments in the epidemiology and control of enzootic bovine leukosis as caused by bovine leukemia virus // Pathogens. 2020. Vol. 9 (12). Article number 1058. DOI:10.3390/pathogens9121058.

2. Yang Y., Fan W., Mao Y., Yang Z., Lu G., Zhang R., Zhang H., Szeto C., Wang C. Bovine leukemia virus infection in cattle of China: Association with reduced milk production and increased somatic cell score // Journal of Dairy Science. 2016. Vol. 99 (5). P. 3688-3697. DOI: 10.3168/jds.2015-10580.

3. Petropavlovskiy M. V., Donnik I. M., Bezborodova N. A., Krivonogova A. S. Detection and immunobiological charcterizons of bovine leukeima virus in Russian Federation territory in dependence on geographical variations // Journal of Integrated OMICS. 2019. Vol. 9 (1). Article number 255. DOI: 10.5584/jiomics.v9i1.255.

4. Turkeev M. K., Mamanova M. K., Daugalieva A. T., Turgenbaev K. A., Kalisynov B. S. Epizootologiya i mery bor'by s leykozom krupnogo rogatogo skota v Respublike Kazakhstan [Epizootology and measures to combat bovine leukemia in the Republic of Kazakhstan] // Sbornik nauchnykh trudov KazNIVI. 2019. T. 65. Pp. 150-157. (In Russian.)

5. Kuzhebayeva U. Zh., Kakishev M. G., Koshemetov Zh. K. Epizooticheskaya situatsiya po leykozu krupnogo rogatogo skota v Zapadno-Kazakhstanskoy oblasti [Epizootic situation of bovine leukemia in the West Kazakhstan region] // Sovremennye vyzovy dlya biotekhnologii, veterinarii i meditsiny: Materialy mezhdunarodnoy nauchnoprakticheskoy konferentsii. Gvardeyskiy, 2020. Pp. 79-84. (In Russian.)

6. Gulyukin M. I., Stepanova T. V., Ivanova L. A., Kozyreva N. G., Shabeykin A. A., Kolomytsev S. A., Lopunov S. V., Barsukov Yu. I. Rasprostranenie i mery bor'by s leykozom krupnogo rogatogo skota $v$ tsentral'nom federal'nom okruge [Distribution and measures to combat bovine leukemia in the Central Federal District] // Veterinariya i kormlenie. 2019. No. 6. Pp. 8-14. (In Russian.)

7. Hamada R., Metwally S., Polat M., Borjigin L., Ali A. O., Abdel-Hady A., Mohamed A., Wada S., Aida Y. A detection and molecular characterization of bovine leukemia virus in Egyptian dairy cattle // Frontiers in Veterinary Science. 2020. Vol. 7 (608). Pp. 1-13. DOI: 10.3389/fvets.2020.00608.

8. Aida Y., Murakami H., Takahashi M., Takeshima S. N. Mechanisms of pathogenesis induced by bovine leukemia virus as a model for human T-cell leukemia virus // Frontiers in Microbiology. 2013. Vol. 4 (328). Pp. 1-8. DOI: 10.3389/fmicb.2013.00328.

9. Lo C.-W., Borjigin L., Saito S., Fukunaga K., Saitou E., Okazaki K., et al. BoLA-DRB3 Polymorphism is associated with differential susceptibility to bovine leukemia virus-induced lymphoma and proviral load // Viruses. 2020. Vol. 12 (3). Article number 352. DOI: 10.3390/v12030352.

10. Zyrianova I. M., Koval'chuk S. N. Bovine leukemia virus pre-miRNA genes' polymorphism // RNA BIOLOGY. 2018. Vol. 15 (12). Pp. 1440-1447. DOI: 10.1080/15476286.2018.1555406.

11. Takeshima S., Ohno A., Aida Y. Bovine leukemia virus proviral load is more strongly associated with bovine major histocompatibility complex class II DRB3 polymorphism than with DQA1 polymorphism in Holstein cow in Japan // Retrovirology. 2019. Vol. 16. Article number 14. DOI: 10.1186/s12977-019-0476-Z.

12. Gil'manov Kh. Kh., Vafin R. R., Karimova R. G., Tyul'kin S. V. Sposob provedeniya PTsR-PDRF dlya genotipirovaniya krupnogo rogatogo skota po allel'nym variantam polimorfnogo markera AH13-1 gena iNOS [The method of PCR-PDRF for cattle genotyping by allelic variants of the polymorphic marker AH13-1 of the alien gene] // Veterinary, Zootechnics and Biotechnology. 2018. No. 4. Pp. 22-28. (In Russian.)

13. Mishchenko V. A., Petrova O. N., Karaulov A. K., Mishchenko A. V. Problema leykoza krupnogo rogatogo skota [The problem of bovine leukemia]. Vladimir: FGBU "VNIIZZh", 2018. 38 p. (In Russian.)

14. Aytnazarov R. B., Ignat'eva E. V., Agarkova T. A., Dvoeglazov N. G., Osipova N. A., Khramtsov V. V., Yudin N. S. Assotsiatsiya odnonukleotidnogo polimorfizma rs110861313 v mezhgennom rayone khromosomy $23 \mathrm{~s}$ 
razvitiem leykoza u krupnogo rogatogo skota cherno-pestroy porody [Association of single nucleotide polymorphism pc110861313 in the intergenic region of chromosome 23 with the development of leukemia in black-and-white cattle] // Vavilov Journal of Genetics and Breeding. 2019. No. 23 (8). Pp. 999-1005. DOI: 10.18699/VJ19.576. (In Russian.)

15. Chichinina S. V. Rol' allel'noy variabel'nosti genov tsitokinov v formirovanii rezistentnosti krupnogo rogatogo skota k leykozu: dis. ... kand. biol. nauk: 16.00.03, 03.00.23 [The role of allelic variability of cytokine genes in the formation of resistance of cattle to leukemia: dissertation ... candidate of biological sciences: 16.00.03, 03.00.23]. Novosibirsk, 2005. 107 p. (In Russian.)

16. Yudin N. S., Podkolodnyy N. L., Agarkova T. A., Ignat'eva E. V. Prioritizatsiya genov, assotsiirovannykh s patogenezom leykoza u krupnogo rogatogo skota [Prioritization of genes associated with the pathogenesis of leukemia in cattle] // Vavilov Journal of Genetics and Breeding. 2018. No. 22 (8). Pp. 1063-1069. DOI: 10.18699/VJ18.451. (In Russian.)

17. Gil'manov Kh. Kh. Genotipirovanie krupnogo rogatogo skota po genam, opredelyayushchim ustoychivost' $\mathrm{k}$ leykozu, i genoidentifikatsiya ego etiologicheskogo agenta: dis... kand.biol.nauk [Genotyping of cattle by genes determining resistance to leukemia and genoidentification of its etiological agent: dissertation ... candidate of biological sciences]. Kazan, 2019. 163 p. (In Russian.)

18. Ivanov D. V. Immunologiya. Immunodefitsity zhivotnykh: uchebnoe posobie [Immunology. Animal immunodeficiency: a textbook]. Bryansk: Bryanskiy GAU, 2019. 154 p. (In Russian.)

19. Stone M. J., Hayward J. A., Huang C., Huma Z. E., Sanchez J. Mechanisms of Regulation of the Chemokine-Receptor Network // International Journal of Molecular Sciences. 2017. Vol. 18 (2). Article number 342. DOI: 10.3390/ ijms 18020342.

20. Arsent'eva N. A., Semenov A. V., Zhebrun D. A., Vasil'eva E.V., Totolyan A.A. Rol' khemokinovogo retseptora CXCR3 i ego ligandov pri nekotorykh immunopatologicheskikh sostoyaniyakh [The role of the chemokine receptor CXCR3 and its ligands in some immunopathological conditions] // Medical Immunology. 2019. T. 21. No. 4. Pp. 617-632. (In Russian.)

21. Cheng Y., Huang C., Tsai H. Relationship of bovine $\mathrm{NOS}_{2}$ gene polymorphisms to the risk of bovine tuberculosis in Holstein cattle // Journal of Veterinary Medical Science. 2016. Vol. 78 (2). Pp. 281-286. DOI: 10.1292/jvms.150295 .

22. Widdison S., Ashley G. R., Howard C. J., Coffey T. J. Characterisation of bovine inducible nitric oxide synthase // Veterinary Immunology and Immunopathology. 2007. Vol. 117 (3-4). Pp. 302-309. DOI: 10.1016/j. vetimm.2007.01.016.

\section{Authors' information:}

Ulbolsyn Zh. Kuzhebayeva' ${ }^{1}$, doctoral student, ORCID 0000-0002-7887-3376, AuthorID 1106962;

+7 747926-12-32,usya_999@mail.ru

Irina M. Donnik ${ }^{2}$, doctor of biological sciences, professor, honorary worker of Higher Professional Education of the Russian Federation, Academician of the Russian Academy of Sciences, Vice President of the Russian Academy of Sciences, ORCID 0000-0002-8593-7470, AuthorID 313786; imdonnik@presidium.ras.ru

Maksim V. Petropavlovskiy², candidate of veterinary sciences, senior researcher of the leukemia laboratory,

ORCID 0000-0002-9892-6092, AuthorID 676746; +7 902 877-46-57,_Petropavlovsky_m@mail.ru

Serik G. Kanatbaev ${ }^{3}$, doctor of biological sciences, professor of the department of ecology and biotechnology, ORCID 0000-0003-0640-4316, AuthorID 336795; +7 777 385-48-46, serik_kg@mail.ru

Birzhan E. Nurgaliev ${ }^{1}$, candidate of veterinary sciences, acting associate professor, head of the Higher School of Veterinary Medicine and Biosafety, ORCID 0000-0001-5998-8250, AuthorID 1063767; +7 747 162-81-23, nurgaliev.79@mail.ru

${ }^{1}$ Zhangir Khan West Kazakhstan Agrarian-Technical University, Uralsk, Kazakhstan

${ }^{2}$ Ural Federal Agrarian Scientific Research Center of Ural Branch of the Russian Academy of Sciences,

Ekaterinburg, Russia

${ }^{3}$ West Kazakhstan innovative and technological University, Uralsk, Kazakhstan 